\title{
Epidemiology of chronic kidney disease in children
}

\author{
Jérôme Harambat • Karlijn J. van Stralen • \\ Jon Jin Kim • E. Jane Tizard
}

Received: 28 April 2011 /Revised: 23 May 2011 /Accepted: 25 May 2011 /Published online: 29 June 2011

(C) The Author(s) 2011 This article is published with open access at Springerlink.com

\begin{abstract}
In the past 30 years there have been major improvements in the care of children with chronic kidney disease (CKD). However, most of the available epidemiological data stem from end-stage renal disease (ESRD) registries and information on the earlier stages of pediatric CKD is still limited. The median reported incidence of renal replacement therapy (RRT) in children aged 0-19 years across the world in 2008 was 9 per million of the agerelated population (4-18 years). The prevalence of RRT in 2008 ranged from 18 to 100 per million of the age-related population. Congenital disorders, including congenital anomalies of the kidney and urinary tract (CAKUT) and hereditary nephropathies, are responsible for about two thirds of all cases of CKD in developed countries, while acquired causes predominate in developing countries. Children with congenital disorders experience a slower progression of CKD than those with glomerulonephritis, resulting in a lower proportion of CAKUT in the ESRD
\end{abstract}

Electronic supplementary material The online version of this article (doi:10.1007/s00467-011-1939-1) contains supplementary material, which is available to authorized users

J. Harambat $\cdot$ K. J. van Stralen

ESPN/ERA-EDTA Registry, Department of Medical Informatics, Academic Medical Center, University of Amsterdam,

Amsterdam, The Netherlands

J. Harambat

University of Bordeaux,

Bordeaux, France

J. J. Kim • E. J. Tizard $(\bowtie)$

Department of Paediatric Nephrology,

Bristol Royal Hospital for Children,

Upper Maudlin Street,

Bristol BS2 8BJ, UK

e-mail: Jane.Tizard@UHBristol.nhs.uk population compared with less advanced stages of CKD. Most children with ESRD start on dialysis and then receive a transplant. While the survival rate of children with ERSD has improved, it remains about 30 times lower than that of healthy peers. Children now mainly die of cardiovascular causes and infection rather than from renal failure.

Keywords Epidemiology Chronic kidney disease . End-stage renal disease $\cdot$ Children $\cdot$ Registry

\section{Introduction}

Chronic kidney disease (CKD) refers to a condition related to irreversible kidney damage that can further progress to endstage renal disease (ESRD). CKD is a major public health problem worldwide and extensive epidemiological research in the adult population is available. In contrast, little is known about the epidemiology of CKD in the pediatric population. ESRD is a devastating disorder associated with excessive mortality and cardiovascular morbidity, and specific problems occur in children, such as impaired growth and psychosocial adjustment, all of which severely impact upon the quality of life [1-3]. A better understanding of the epidemiology of CKD in children is essential in order to make a precise and early diagnosis, identify preventable or reversible causes of progression, predict prognosis, and aid the counseling of the children and their families.

\section{Definition of CKD}

A possible reason for the limited information on the epidemiology of CKD in the pediatric population is the historical absence of a common definition and well-defined 
classification of CKD. In 2002, the National Kidney Foundation's Kidney Disease Outcomes Quality Initiative (NKF-K/ DOQI) published a guideline on CKD, which included a classification system for CKD severity, independent of cause, and applicable to children [4]. Prior to the introduction of this classification, various thresholds were used. For example, the ItalKid Project, a prospective, population-based Italian study on CKD epidemiology, and the North American Pediatric Renal Trials and Collaborative Studies (NAPRTCS), defined CKD as having a glomerular filtration rate (GFR) of below $75 \mathrm{ml} / \mathrm{min} / 1.73 \mathrm{~m}^{2}[5,6]$. Others based their definition on serum creatinine levels themselves or on other thresholds of GFR [7-9]. The K/DOQI classification system identifies five stages of CKD based on the level of GFR. CKD is now defined by a presence of kidney damage (for example, any structural or functional abnormality involving pathological, laboratory or imaging findings) for $\geq 3$ months or a GFR $<$ $60 \mathrm{ml} / \mathrm{min} / 1.73 \mathrm{~m}^{2}$ for $\geq 3$ months. The new classification was widely adopted after its introduction; however, its limitations and possible modifications have been a matter of extensive discussion [10]. In children, the currently available methods of estimating GFR are evolving, but a proper assessment of renal function by estimated GFR formulae remains challenging, particularly in the early stages of kidney injury [11]. For example, the K/DOQI classification does not apply to children under 2 years of age as GFR increases from birth and reaches normal adult values by 2 years of age [4]. Furthermore, children born with major structural anomalies will be considered to have CKD before waiting 3 months for such a diagnosis.

\section{Causes of CKD}

Causes of CKD are very different in children from those in adults. In the United States, the registry of the NAPRTCS has collected data on the early stages of CKD in children since 1994 [6]. The NAPRTCS Registry receives data from pediatric nephrology centers on a voluntary basis and includes more than 7,000 children aged under 21 years, providing a large source of information on the etiology of CKD in childhood [12]. In a recent NAPRTCS report congenital causes, including congenital anomalies of the kidney and urinary tract (CAKUT) (48\%) and hereditary nephropathies $(10 \%)$, were the most common (Table 1). Glomerulonephritis accounted for $14 \%$ of cases. The distribution of causes varied with age. Whereas CAKUT predominated in younger patients, glomerulonephritis was the leading cause in children older than 12 years of age. Causes of CKD vary across races, for example, focal segmental glomerulosclerosis, the main cause of glomerular disease, was three times more common in blacks than in whites (19 vs 6\%) and especially among black adolescents
(35\%) [12]. A fairly similar distribution of causes of CKD has been reported in Europe by the Italian and the Belgian registries $[5,13]$. The proportions of CAKUT $(58-59 \%)$ and hereditary nephropathy (15-19\%) were slightly higher, while the proportion of glomerulonephritis was lower (5$7 \%$ ) than in the NAPRTCS database, possibly because of the difference in racial distribution.

In view of a dearth of national registries and surveys, estimating the causes of CKD in children in low and middle income countries is difficult. In Turkey and other countries in the Middle East, CAKUT is the leading cause of CKD $(47-62 \%)$ with a clear predominance of uropathies over hypodysplasia followed by hereditary nephropathies (17 to $30 \%)[9,14-16]$. Of note, neuropathic bladder remained an important cause of CKD in Turkey $(15 \%)$, while it accounted for about $4 \%$ in Italy and Belgium. These figures may reflect a delay in appropriate urological diagnosis and treatment. In addition, the higher proportion of genetic diseases found in the Middle East than in Europe may be explained by a higher prevalence of consanguineous marriages. Chronic glomerulonephritis is the main reported cause of CKD in various studies from India, Southeast Asia, Latin America and Caribbean area and subSaharan Africa, with a prevalence ranging from 30 to almost $60 \%$ [17-25]. Such high proportions of glomerulonephritis may be related to high prevalence of bacterial, viral, and parasitic infections that commonly affect the kidneys in developing countries, as well as a different age distribution in these reports where patients are referred in the later stages of CKD.

In the United States Renal Data System (URDS) Registry, congenital disorders (CAKUT and hereditary nephropathies) were the most common etiologies in the youngest ESRD group, whereas the proportion of acquired diseases increased progressively with age [26]. Overall, CAKUT are the main causes, accounting for $34-43 \%$ of pediatric ESRD cases in Europe, Japan, Australia, and New Zealand (Table 1) [27-30]. In 2008, the proportion of ESRD caused by glomerulonephritis was lower in Europe according to the ESPN/ERA-EDTA registry (15\%) compared with a Japanese study (22\%) and the Australia and New Zealand Dialysis and Transplant Registry (ANZDATA; 29\%). The ANZDATA Registry showed a decline in glomerulonephritis as a cause of ESRD over time. However, this may be due to the age distribution of patients, with fewer young patients being treated for ESRD at that time. There was also a decline in the proportion of ESRD caused by reflux nephropathy, while obstructive uropathy and hypodysplasia increased [31]. This trend may be explained by a change in reporting the primary diagnosis, since the combined proportion of hypodysplasia and reflux nephropathy has remained stable over the past 30 years. 


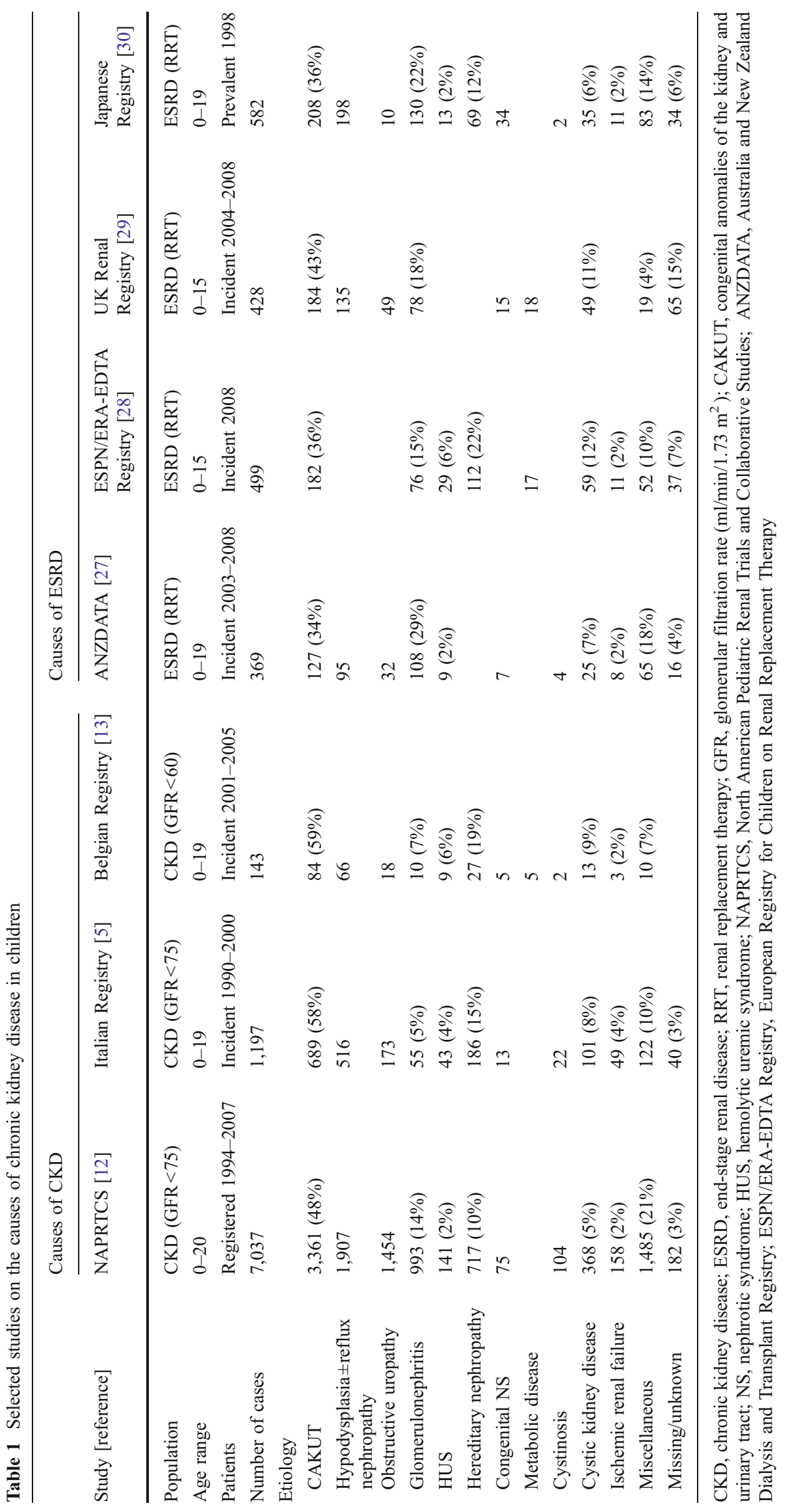




\section{Screening for early kidney injury}

While screening and surveillance of CKD in adults, either population-based or targeted at-risk populations, have become important parts of CKD prevention strategies worldwide, the benefit of such programs in children is much more controversial [32]. Tests used for CKD screening in children are usually limited to urinary dipstick protein instead of urine albumin/creatinine ratio or creatinine-based calculation of estimated GFR, as recommended for adults. However, there is a large variation in the methods used and approaches taken by different countries, and the findings have shown poor reproducibility (Table S1 and references in ESM).

Mass screening programs to detect CKD in children have been well established for many years in several Asian countries, such as Japan, Taiwan, and Korea [33-35]. Conversely, screening programs have not been adopted in Europe, but urine screening dipsticks have routinely been used in healthy children for decades in the United States. In 2000, the recommendations from the American Academy of Pediatrics were to screen urine in two groups: preschool children and adolescents [36]. This policy was revised in 2007; thus, this practice is no longer recommended [37]. Although a decrease in the incidence of ESRD has been observed in Japan and Taiwan, there is only limited evidence that early detection of kidney injury in children may lead to effective interventions to slow the progression of CKD and to further reduce the risk of developing ESRD [32]. Furthermore, recent studies suggest that a urine dipstick is not cost-effective in screening children [38].

\section{Demographics of CKD}

There is limited information on the epidemiology of the early stages of CKD in the pediatric population as it is often asymptomatic and therefore under-diagnosed and underreported. Although some pediatric CKD registries using K/ DOQI classification are beginning to emerge, only a few reports on the epidemiology of CKD stages 2 to 5 in children are available, and even less is known about lowincome countries. For these countries, data is mostly obtained from reports of major tertiary care referral centers, but the validity of this data is variable.

\section{Europe}

Several pediatric nephrology societies from European countries have provided data on the early stages of CKD (Table 2) $[5,7,8,13,14,39]$. Even though age categories and the definition of CKD differed among countries, the incidence in Europe was fairly consistent, being around 11-

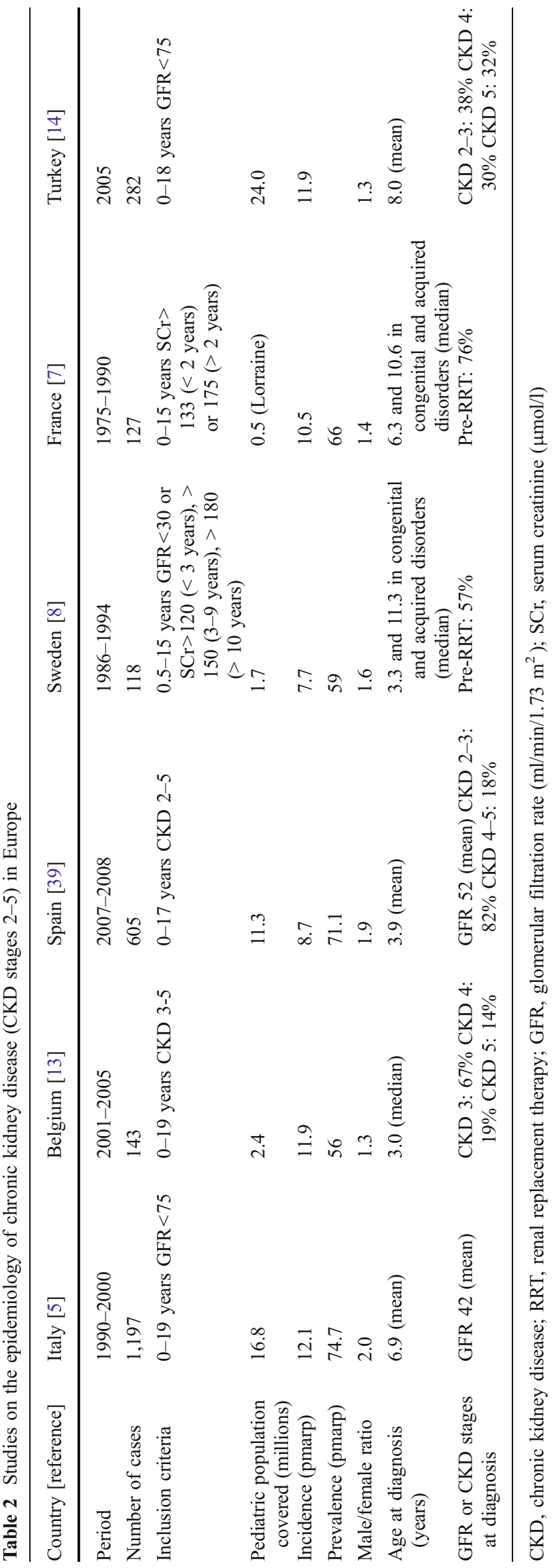


12 per million of the age-related population (pmarp) for CKD stages 3-5, and 8 pmarp for CKD stages 4-5. While an increase in incidence since the 1970s was seen in France, this was not shown in Sweden [8, 40]. Prevalence ranged from about 55-60 to 70-75 pmarp in Spain and Italy, depending on the clinical definition of CKD that was used in each study. Another consistent finding was the predominance of the male gender (male/female ratio ranging from 1.3 to 2.0 ) reflecting in particular the higher incidence of CAKUT in boys than in girls.

\section{Latin America}

In Chile, a national survey of pediatric nephrologists estimated an incidence of CKD $\left(\mathrm{GFR}<30 \mathrm{ml} / \mathrm{min} / 1.73 \mathrm{~m}^{2}\right)$ in children aged less than 18 years of 5.7 pmarp and a prevalence of 42.5 pmarp in 1996 [41]. Among these patients, half were on conservative treatment and the others were on renal replacement therapy (RRT). A study on the epidemiology of CKD conducted in several Latin American countries (Argentina, Brazil, Chile, Colombia, Mexico, Uruguay, and Venezuela) showed a wide variation in incidence that ranged from 2.8 to 15.8 new cases pmarp [42].

\section{Middle East and South East Asia}

The referral center for pediatric kidney diseases in Kuwait provided data on children aged $0-15$ years with a GFR $<$ $50 \mathrm{ml} / \mathrm{min} / 1.73 \mathrm{~m}^{2}$ [9]. The mean incidence was found to be as high as 38 pmarp, whereas the prevalence increased from 188 in 1996 to a rate as high as 329 pmarp in 2003 . The marked difference in incidence between Kuwaiti children and non-Kuwaiti residents suggested a role of genetic factors [9]. An incidence of 11 pmarp and a prevalence of 51 pmarp have been reported in Jordanian children [16]. Two reports from Vietnam have suggested an annual incidence of hospitalization for CKD of around 5 pmarp, and most of the patients had already reached ESRD [19, 20].

\section{Sub-Saharan Africa}

Single-center studies from sub-Saharan Africa have shown a very low incidence of CKD, estimated at 3 pmarp in Nigeria, which did not offer pediatric RRT, and 1-2 pmarp in South Africa [23, 24].

\section{Demographics of ESRD}

Incidence and prevalence of ESRD

There are marked variations in the incidence and prevalence of ESRD in the pediatric population across countries. Approximately $80 \%$ of RRT patients worldwide live in Europe, Japan or North America, where all children with ESRD have access to RRT. By contrast, limited health care resources and lack of trained personnel in developing countries result in rationing of or even not offering RRT.

In 2008, the median incidence of RRT in children aged less than 20 years was around 9 pmarp, varying from less than 4 (Russia) to 18 pmarp (New Zealand; Fig. 1). The incidence of RRT was 9.5 pmarp among 11 western European countries

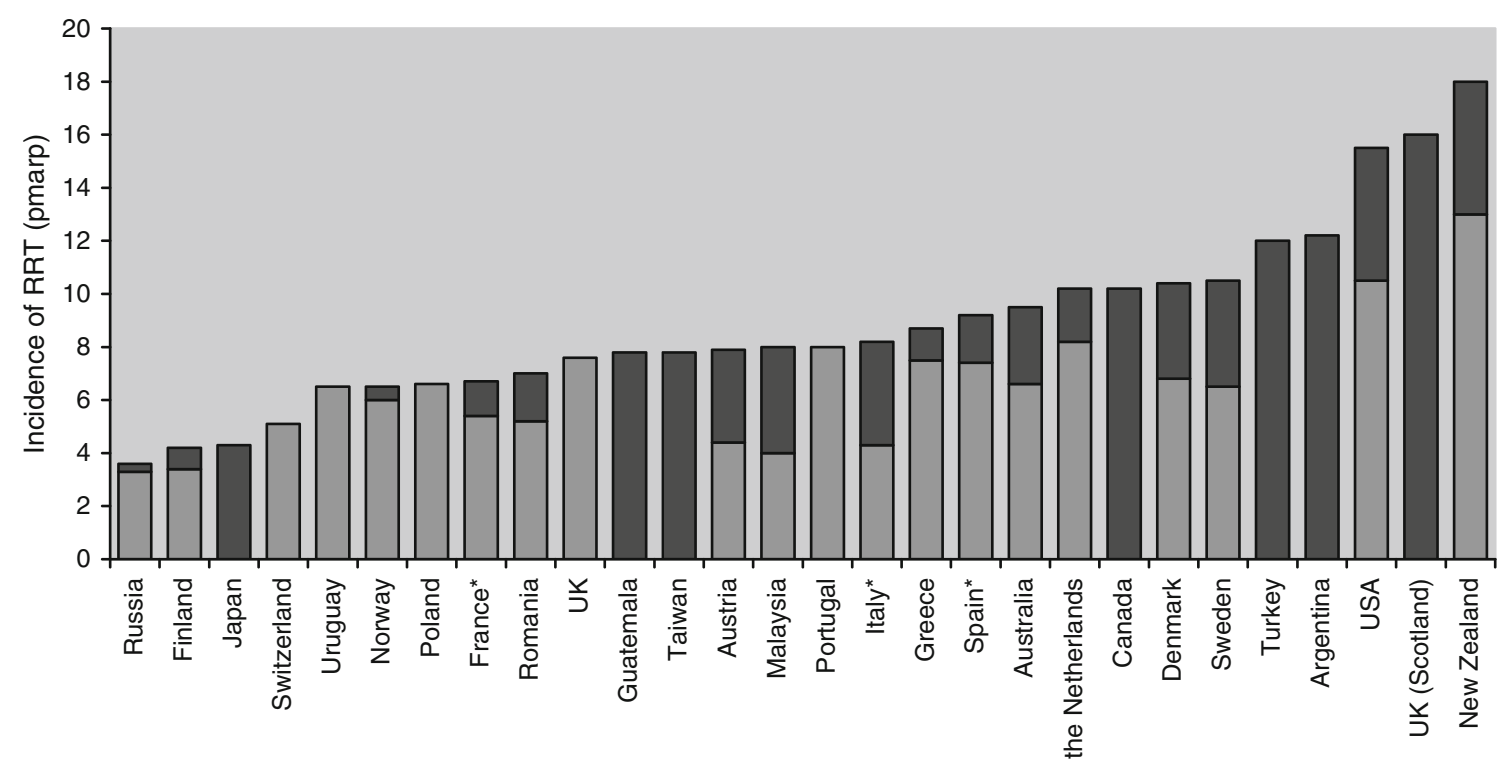

Fig. 1 Incidence of renal replacement therapy (RRT) in children in 2008 by country. The light bars correspond to the incidence in children aged 0-14 years, the sum of the light and the dark bars corresponds to the incidence in children aged 0-19 years. *France 16 out of 26 regions, Italy 13 out of 20 regions, Spain 4 out of 18 regions in the 15- to 19-year-old age group 


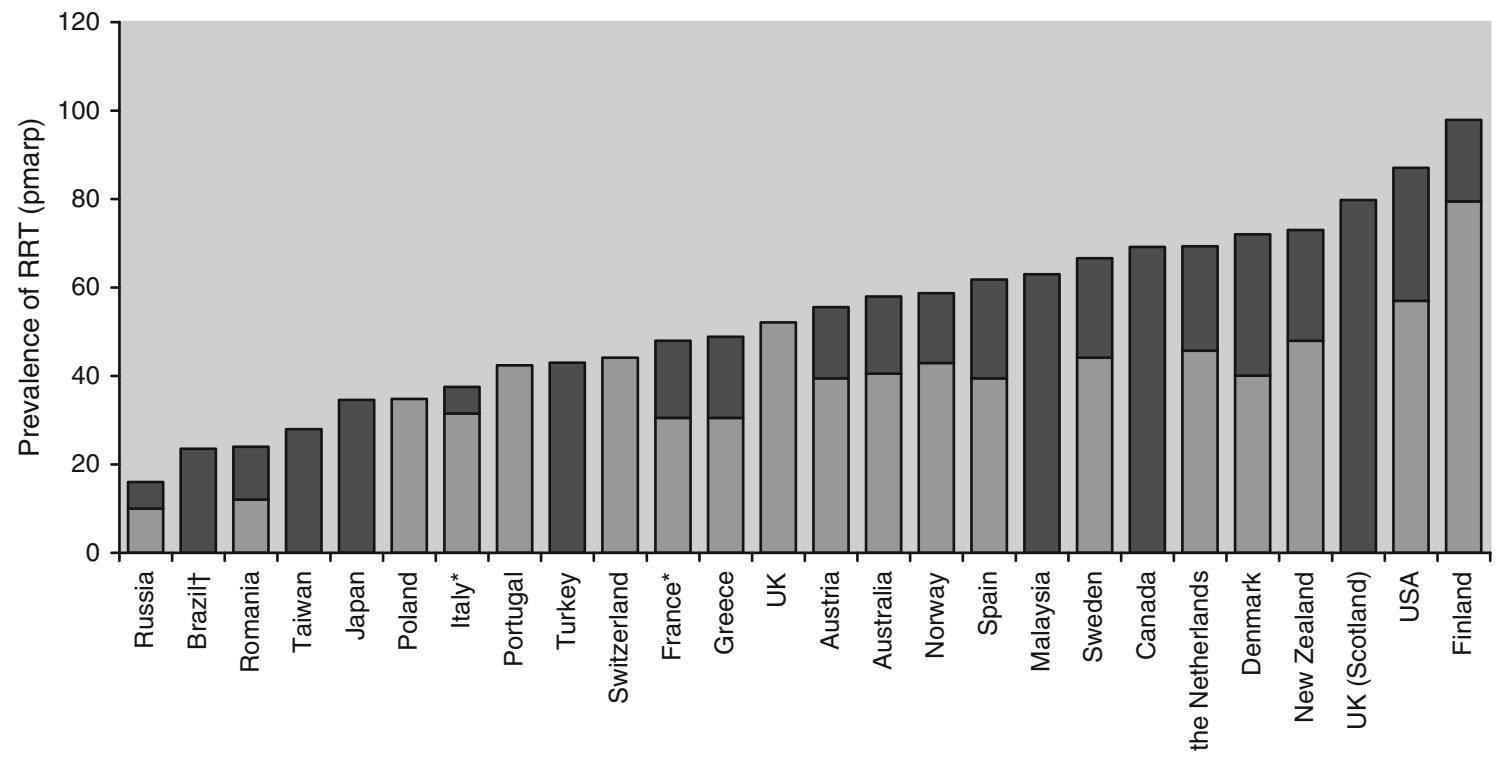

Fig. 2 Prevalence of RRT in children on 31 December 2008 by country. The light bars correspond to the prevalence in children aged 0-14 years, the sum of the light and the dark bars corresponds to the prevalence in children aged $0-19$ years. *France 16 out of 26 regions, Italy 13 out of 20 regions, Spain 4 out of 18 regions in the 15-19year-old age group; ${ }^{\dagger}$ State of Sao Paulo

RRT (Fig. 2). The prevalence was higher in the United States (85 pmarp), whilst Japan had a lower prevalence (34 pmarp). A recent survey conducted in the most populated Brazilian State showed a prevalence of 23 pmarp in children less than 18 years of age (Dr Koch Nogueira, personal communication, used with permisson). Incidence and prevalence also differ by race. African-American children had an almost two-fold greater incidence of ESRD compared with white children [26], while in Australia and New Zealand, kidney disease is more common in Maori, Pacific Island, and indigenous Australian people than in non-indigenous people, although the difference in incidence of ESRD is mainly among those over the age of 15 years [49]. In the UK, the prevalence and the incidence of RRT in children from the south Asian population in 2008 were 2.5 and 1.5 times greater than that of the white population aged $0-15$ years [29].

\section{Changing trends}

In the United States, the adjusted annual incidence of ESRD in the pediatric population rose slowly during the 1980s, and then increased marginally from 14 to 15 pmarp between 1990 and 2008 [26]. The adjusted prevalence increased from 60 to 85 in the same period. The incidence of ESRD in children aged less than 18 years from Australia and New Zealand has remained constant at about 8 pmarp over the past 25 years, while the prevalence of RRT increased from approximately 30 to 50 pmarp [31]. A report from the EDTA registry on patients aged 0-19 years starting RRT between 1980 and 2000 in 12 western European countries showed that the 
Table 3 Comparison of RRT modalities within registries in children*

\begin{tabular}{|c|c|c|c|c|c|c|c|}
\hline \multirow[t]{2}{*}{ Registry (number of countries) } & \multirow[t]{2}{*}{ Age (years) } & \multicolumn{3}{|c|}{ Initial treatment modality (\%) } & \multicolumn{3}{|c|}{ Prevalent treatment modality $(\%)$} \\
\hline & & HD & $\mathrm{PD}$ & Transplantation & HD & PD & Transplantation \\
\hline ANZDATA (2) & $0-19$ & 45 & 39 & 16 & 12 & 15 & 73 \\
\hline ERA-EDTA (11) & $0-19$ & 44 & 35 & 21 & 13 & 7 & 80 \\
\hline ESPN/ERA-EDTA (31) & $0-14$ & 36 & 49 & 15 & 14 & 21 & 65 \\
\hline \multirow[t]{2}{*}{ USRDS (1) } & $0-19$ & 52 & 31 & 17 & 17 & 11 & 71 \\
\hline & $0-14$ & 35 & 46 & 19 & 15 & 11 & 74 \\
\hline CORR/Canada (1) & $0-19$ & 52 & 30 & 18 & 9 & 13 & 78 \\
\hline Japan (1) & $0-18$ & 30 & 69 & 1 & 17 & 42 & 41 \\
\hline
\end{tabular}

USRDS, US Renal Data System; CORR, Canadian Organ Replacement Register

* Prevalence at 31 December 2008, except data from Japan at 1 January 1998, incidence reported from data in 2008 (ESPN/ERA-EDTA and USRDS), 2003-2008 (ANZDATA), 2007-2008 (ERA-EDTA), 2007-2009 (CORR), and 1998 (Japan)

incidence of RRT rose from 7 pmarp in 1980-1984 to 10 pmarp in 1985-1989, and remained stable thereafter [50]. The prevalence increased from 22.9 pmarp in 1980 to 62 pmarp in 2000. The increase in prevalence is explained by improved survival and treatment of younger children.

\section{Treatment modalities}

Countries vary considerably in the distribution of initial treatment modality [50]. Some countries, like Japan or Turkey, preferentially use peritoneal dialysis (PD) [27, 51], but in most registries about half of children younger than 20 years of age commenced RRT with hemodialysis (HD; Table 3). Initial RRT varies with age since PD is the preferred choice in children aged 0-14 years in Europe and the United States, whereas three-quarters of children aged 15-19 years start with HD [26, 43]. This may reflect the management of many adolescents in adult units where HD is more likely to be proposed than in pediatric units. Registry data have shown that $65-80 \%$ of children and adolescents on RRT programs have a kidney transplant (Table 3), with the exception of Japan where the transplantation rate was very low in data from 1998.

In developing countries, dialysis is often not offered. Survival therefore depends on the development of locally appropriate transplant programs. The lack of deceased donors might lead to pressure on relatives to become living donors and a trade in paid organ donation.

\section{Mortality and morbidity}

At the start of RRT programs in the 1960s, the case-fatality rate was 11.0 per 100 patient years [52]. Since then, there has been much improvement, now showing a stable case-fatality rate of 1.3-1.8 per 100 patient years in the past 15 years $[50,52]$. Survival is similar throughout the developed world [52-54], but still the mortality rate in children with RRT is about 30 times higher than in their healthy peers [52, 53]. Infants with severe renal disease are at higher risk of death in the first 2 years of life, but outcomes thereafter are comparable to those of older children [55]. Transplant patients consistently have up to a 4-fold survival benefit compared with dialysis patients [45, 52]. Among young adults who started RRT during childhood, the average life expectancy was 63 years for those with a functioning graft compared with 38 years for those remaining on dialysis [56]. Other risk factors for a higher mortality include the presence of co-morbidities, and long standing hypertension [52, 53]. The two major causes of mortality in pediatric RRT are cardiovascular disease and infections, accounting for 30 $40 \%$ and $20-50 \%$ of deaths respectively [12, 45, 52, 53]. Also, the burden of morbidity from cardiovascular disease and infections is high, as, for example, infections caused 600 admissions per 1,000 patient years and cardiovascular disease 350 admissions per 1,000 patient years in the first month of starting dialysis, according to the most recent USRDS report [26]. In transplant patients, infection has overtaken acute rejection as the primary cause of hospital admissions [57].

\section{Progression of CKD}

The progression of CKD is variable and depends on the underlying disease, the severity of the initial injury, and the presence of additional risk factors. Data from the NAPRTCS on more than 4,000 children with CKD stages $2-4$ showed a progression rate to ESRD of $17 \%$ at 1 year and $39 \%$ at 3 years following registration, with a median time to ESRD of 4.5 years [58]. The rate of progression was inversely proportional to baseline GFR. In the ItalKid project, the incidence of RRT was 7.3 per year per 100 patients with CKD, and the risk of ESRD was $68 \%$ by the age of 20 years [5]. 
Nonmodifiable progression factors

Children with congenital disorders experience a slower progression of CKD than those with glomerulonephritis, resulting in a relatively decreased proportion of hypodysplasia and uropathies in the RRT population compared with less advanced stages of CKD. Also, the rate of progression of CKD is usually greater during puberty $[5,59]$. Potential mechanisms include a higher blood pressure, imbalance between residual nephron mass and filtration demands during this period of rapid change in body size, as well as altered endocrine physiology. A low birth weight is associated with a lower number of nephrons, which might predispose to hypertension and CKD in later life [60].

Although it has been clearly established that many ethnic minorities suffer a greater incidence of ESRD compared with whites [26, 29], the evidence to date does not show ethnic differences in the rates of progression of CKD in children. Possible confounders, such as unequal access to care, are difficult to assess.

Finally, genetic predisposition may influence the rate of progression of CKD. Several recent genome-wide association studies have identified genetic loci that relate to CKD susceptibility and progression in adults [61].

\section{Modifiable progression factors}

Hypertension and proteinuria are the most important independent risk factors for renal disease progression in both adult and pediatric CKD [62-64]. Hypertension is present in approximately $50 \%$ of children with CKD and masked hypertension (i.e., normal casual but elevated ambulatory blood pressure) is often present $[65,66]$. The ESCAPE study group showed that strict blood pressure control under the 50th percentile slows pediatric CKD progression during 5 years' follow-up [67]. In the ESCAPE trial, the initial antiproteinuric response to angiotensin-converting enzyme inhibitor therapy was predictive of renal survival, despite the occurrence of a proteinuria rebound in half of the patients [67]. There is clear evidence in adults that obesity is associated with an increased risk of development and progression of kidney disease [68]. A similar association has also been documented in obese children, even though there is a lack of large and long-term follow-up studies [69]. Other factors potentially involved in the progression of CKD have been addressed in adult patients, including metabolic acidosis, anemia, altered calcium-phosphate homeostasis, chronic inflammation, and metabolic factors, such as diabetes, hyperuricemia, dyslipidemia, and smoking [70-75]. Pediatric retrospective data suggest that many factors such as anemia, hypoalbuminemia, hyperphosphatemia, and hypocalcemia might be associated with the rate of CKD progression, implying potential measures to preserve renal function $[59,76]$. However, these data require confirmation from ongoing prospective cohort studies on pediatric CKD [77, 78].

\section{Conclusion}

Recent years have shown a tremendous increase in the amount of available data on CKD and ESRD in children. Nevertheless, there are still only limited data on the earlier stages of CKD. As numbers of patients are small, more research is needed to improve the understanding of the differences in incidence between countries, causes and progression of CKD in order to prevent renal failure, as well as improved quality of care among patients with ESRD. To allow for international comparisons in future studies, we recommend using the $\mathrm{K} / \mathrm{DOQI}$ guidelines to define the stages of CKD and publishing data for similar age groups (by showing separate data for children aged 0 14 years and what is available above 15 years of age).

Acknowledgements We gratefully acknowledge Dr Motoshi Hattori (Japanese Society for Pediatric Nephrology, Tokyo Women's Medical University, Japan), Dr Rajani Hada (Bir Hospital, Kathmandu, Nepal), Dr Chiu-Ching Huang (Taiwan Renal Registry, China Medical University Hospital, Taiwan), Dr Paulo Koch Nogueira (Universidade Federal de São Paulo, Brazil), Dr Randall Lou-Meda (FUNDANIER, Hospital Roosevelt, Guatemala City, Guatemala), Dr Steven McTaggart (ANZDATA Registry, Royal Children's Hospital, Brisbane, Australia), Dr Elena Molchanova (Russian Pediatric Registry of RRT, Russian Children Clinical Hospital, Moscow, Russia), Dr Nelson Orta-Sibu (ALANEPE Latin American Pediatric Nephrology Association, Hospital Universitario de Valencia, Venezuela) for providing epidemiological data. Jérôme Harambat was supported by an ERA-EDTA QUEST initiative research fund.

Open Access This article is distributed under the terms of the Creative Commons Attribution Noncommercial License which permits any noncommercial use, distribution, and reproduction in any medium, provided the original author(s) and source are credited.

\section{Questions (Answers appear following the reference list)}

1. Which of the following statements regarding CKD is false?

a) The KDOQI guidelines define $\mathrm{CKD}$ as a GFR $<$ $50 \mathrm{ml} / \mathrm{min} / 1.73 \mathrm{~m}^{2}$

b) GFR increases from birth and reaches adult values by 2 years of age

c) CAKUT is the major cause of CKD worldwide, although the proportion of glomerulonephritis in developing countries is higher due to infectious causes

d) There are few population-based studies in the early stages of CKD as it is often asymptomatic

2. Which of the following statements regarding screening in children is true?

a) Screening is currently recommended in children in the USA by the American Academy of Pediatrics 
b) Screening has been proven to reduce the development of ESRD

c) Screening mainly employs dipsticks in children, as opposed to calculating GFR in adults

d) Urine dipstick testing is a cost-effective strategy for detecting CKD

3. Which of the following statements regarding ESRD is false?

a) Prevalence of ESRD is increasing owing to better overall survival and increased uptake of younger children and infants into RRT programs

b) The prevalence of RRT in 2008 in Australia, Canada, and western Europe (except Finland) is around 65 pmarp

c) Access to ESRD programs is highly dependent on socio-economic factors and as such, is limited in poorly developed countries

d) Incidence of ESRD varies depending on age and ethnic group

e) The majority of children are transplanted pre-emptively

4. Which of the following regarding mortality and morbidity is false?

a) The mortality rate has remained relatively unchanged in the last 15 years and is about 30 times higher than in healthy peers

b) Children on dialysis have a higher mortality rate compared with transplanted patients

c) Rejection is the main cause of admission in transplanted children

d) $20-40 \%$ of deaths in RRT are cardiovascular-related

5. Which of the following statements regarding CKD progression is not true?

a) Hypertension is a major risk factor for CKD progression

b) Hyperphosphatemia is an independent risk factor for CKD progression, as has been shown in prospective studies

c) There is evidence that the progression of CKD can be slowed by pharmacological intervention

d) The rate of CKD progression is inversely proportional to baseline GFR

e) Children with congenital disorders experience a slower progression of CKD than those with glomerulonephritis

\section{References}

1. Greenbaum LA, Warady BA, Furth SL (2009) Current advances in chronic kidney disease in children: growth, cardiovascular, and neurocognitive risk factors. Semin Nephrol 29:425-434
2. Shroff R, Ledermann S (2009) Long-term outcome of chronic dialysis in children. Pediatr Nephrol 24:463-474

3. Rees L (2009) Long-term outcome after renal transplantation in childhood. Pediatr Nephrol 24:475-484

4. Hogg RJ, Furth S, Lemley KV, Portman R, Schwartz GJ, Coresh J, Balk E, Lau J, Levin A, Kausz AT, Eknoyan G, Levey AS, (2003) National Kidney Foundation's Kidney Disease Outcomes Quality Initiative clinical practice guidelines for chronic kidney disease in children and adolescents: evaluation, classification, and stratification. Pediatrics 111:1416-1421

5. Ardissino G, Daccò V, Testa S, Bonaudo R, Claris-Appiani A, Taioli E, Marra G, Edefonti A, Sereni F; ItalKid Project (2003) Epidemiology of chronic renal failure in children: data from the ItalKid project. Pediatrics 111:e382-e387

6. Fivush BA, Jabs K, Neu AM, Sullivan EK, Feld L, Kohaut E, Fine R (1998) Chronic renal insufficiency in children and adolescents: the 1996 annual report of NAPRTCS. North American Pediatric Renal Transplant Cooperative Study. Pediatr Nephrol 12:328-337

7. Deleau J, Andre JL, Briancon S, Musse JP (1994) Chronic renal failure in children: an epidemiological survey in Lorraine (France) 1975-1990. Pediatr Nephrol 8:472-476

8. Esbjörner E, Berg U, Hansson S (1997) Epidemiology of chronic renal failure in children: a report from Sweden 1986-1994. Swedish Pediatric Nephrology Association. Pediatr Nephrol 11:438-442

9. Al-Eisa A, Naseef M, Al-Hamad N, Pinto R, Al-Shimeri N, Tahmaz M (2005) Chronic renal failure in Kuwaiti children: an eight-year experience. Pediatr Nephrol 20:1781-1785

10. Eckardt KU, Berns JS, Rocco MV, Kasiske BL (2009) Definition and classification of CKD: the debate should be about patient prognosis - a position statement from KDOQI and KDIGO. Am J Kidney Dis 53:915-920

11. Schwartz GJ, Muñoz A, Schneider MF, Mak RH, Kaskel F, Warady BA, Furth SL (2009) New equations to estimate GFR in children with CKD. J Am Soc Nephrol 20:629-637

12. North American Pediatric Renal Transplant Cooperative Study (NAPRTCS) (2008) 2008 Annual report. The EMMES Corporation, Rockville, MD

13. Mong Hiep TT, Ismaili K, Collart F, Van Damme-Lombaerts R, Godefroid N, Ghuysen MS, Van Hoeck K, Raes A, Janssen F, Robert A (2010) Clinical characteristics and outcomes of children with stage 3-5 chronic kidney disease. Pediatr Nephrol 25:935-940

14. Bek K, Akman S, Bilge I, Topaloğlu R, Calişkan S, Peru H, Cengiz N, Söylemezoğlu O (2009) Chronic kidney disease in children in Turkey. Pediatr Nephrol 24:797-806

15. Madani K, Otoukesh H, Rastegar A, Van Why S (2001) Chronic renal failure in Iranian children. Pediatr Nephrol 16:140-144

16. Hamed RM (2002) The spectrum of chronic renal failure among Jordanian children. J Nephrol 15:130-135

17. Gulati S, Mittal S, Sharma RK, Gupta A (1999) Etiology and outcome of chronic renal failure in Indian children. Pediatr Nephrol 13:594-596

18. Vachvanichsanong P, Dissaneewate P, McNeil E (2008) Childhood chronic kidney disease in a developing country. Pediatr Nephrol 23:1143-1147

19. Mong Hiep TT, Janssen F, Ismaili K, Khai Minh D, Vuong Kiet D, Robert A (2008) Etiology and outcome of chronic renal failure in hospitalized children in Ho Chi Minh City, Vietnam. Pediatr Nephrol 23:965-970

20. Huong NT, Long TD, Bouissou F, Liem NT, Truong DM, Nga do K, Chien TT, Bascands JL (2009) Chronic kidney disease in children: the National Paediatric Hospital experience in Hanoi, Vietnam. Nephrology (Carlton) 14:722-727

21. Orta-Sibu N, Lopez M, Moriyon JC, Chavez JB (2002) Renal diseases in children in Venezuela, South America. Pediatr Nephrol 17:566-569 
22. Miller ME, Williams JA (2009) Chronic renal failure in Jamaican children - an update (2001-2006). West Indian Med J 58:231-234

23. Anochie I, Eke F (2003) Chronic renal failure in children: a report from Port Harcourt, Nigeria (1985-2000). Pediatr Nephrol 18:692-695

24. Bhimma R, Adhikari M, Asharam K, Connolly C (2008) The spectrum of chronic kidney disease (stages 2-5) in KwaZuluNatal, South Africa. Pediatr Nephrol 23:1841-1846

25. Ali el-TM, Abdelraheem MB, Mohamed RM, Hassan EG, Watson AR (2009) Chronic renal failure in Sudanese children: aetiology and outcomes. Pediatr Nephrol 24:349-353

26. US Renal Data System, USRDS (2010) Annual data report: atlas of chronic kidney disease and end-stage renal disease in the United States. National Institutes of Health, National Institute of Diabetes and Digestive and Kidney Diseases, Bethesda, MD

27. McTaggart S, McDonald S, Henning P, Dent H (2009) Paediatric Report. ANZDATA Registry Report 2009, Australia and New Zealand Dialysis and Transplant Registry. Adelaide, South Australia

28. ESPN/ERA-EDTA Registry (2010) ESPN/ERA-EDTA registry annual report 2008. http://www.espn-reg.org/

29. Lewis MA, Shaw J, Sinha MD, Adalat S, Hussain F, Castledine C, van Schalkwyk D, Inward C (2010) UK Renal Registry 12th Annual Report (December 2009): chapter 14: demography of the UK paediatric renal replacement therapy population in 2008 . Nephron Clin Pract 115:c279-c288

30. Hattori S, Yosioka K, Honda M, Ito H, Japanese Society for Pediatric Nephrology (2002) The 1998 report of the Japanese National Registry data on pediatric end-stage renal disease patients. Pediatr Nephrol 17:456-461

31. Orr NI, McDonald SP, McTaggart S, Henning P, Craig JC (2009) Frequency, etiology and treatment of childhood end-stage kidney disease in Australia and New Zealand. Pediatr Nephrol 24:17191726

32. Hogg RJ (2009) Screening for CKD in children: a global controversy. Clin J Am Soc Nephrol 4:509-515

33. Murakami M, Hayakawa M, Yanagihara T, Hukunaga Y (2005) Proteinuria screening for children. Kidney Int Suppl (94):S23-S27

34. Lin CY, Sheng CC, Chen CH, Lin CC, Chou P (2000) The prevalence of heavy proteinuria and progression risk factors in children undergoing urinary screening. Pediatr Nephrol 14:953959

35. Cho BS, Kim SD (2007) School urinalysis screening in Korea. Nephrology (Carlton) 12:S3-S7

36. Committee on Practice and Ambulatory Medicine (2000) Recommendations for preventive pediatric health care. Pediatrics 105:645-646

37. Committee on Practice and Ambulatory Medicine and Bright Futures Steering Committee (2007) Recommendations for preventive pediatric health care. Pediatrics 120:1376

38. Sekhar DL, Wang L, Hollenbeak CS, Widome MD, Paul IM (2010) A cost-effectiveness analysis of screening urine dipsticks in well-child care. Pediatrics 125:660-663

39. Areses Trapote R, Sanahuja Ibáñez MJ, Navarro M, Investigadores Centros Participantes en el REPIR II (2010) Epidemiology of chronic kidney disease in Spanish pediatric population. REPIR II Project. Nefrologia 30:508-517

40. Esbjörner E, Aronson S, Berg U, Jodal U, Linne T (1990) Children with chronic renal failure in Sweden 1978-1985. Pediatr Nephrol 4:249-252

41. Lagomarsimo E, Valenzuela A, Cavagnaro F, Solar E (1999) Chronic renal failure in pediatrics 1996. Chilean survey. Pediatr Nephrol 13:288-291

42. Orta-Sibu N, Exeni RA, Garcia C (2009) Latin America. In: Avner ED, Harmon WE, Niaudet P, Yoshikawa N (eds) Pediatric Nephrology. Springer-Verlag, Heidelberg, pp 1969-1974
43. Registry ERA-EDTA (2010) ERA-EDTA Registry Annual Report 2008. Academic Medical Center, Department of Medical Informatics, Amsterdam, The Netherlands

44. Van Stralen KJ, Tizard EJ, Jager KJ, Schaefer F, Vondrak K, Groothoff JW, Podracká L, Holmberg C, Jankauskiené A, Lewis MA, van Damme-Lombaerts R, Mota C, Niaudet P, Novljan G, Peco-Antic A, Sahpazova E, Toots U, Verrina E (2010) Determinants of eGFR at start of renal replacement therapy in paediatric patients. Nephrol Dial Transplant 25:3325-3332

45. US Renal Data System, USRDS (2008) Annual data report: atlas of chronic kidney disease and end-stage renal disease in the United States. National Institutes of Health, National Institute of Diabetes and Digestive and Kidney Diseases, Bethesda, MD

46. Lim YN, Lim TO (2009) 16th Report of the Malaysian Dialysis and Transplant 2008, Kuala Lumpur

47. Garcia C, Goldani J, Garcia V (1992) Paediatric dialysis and renal transplantation in the state of Rio Grande do Sul, Brazil. Pediatr Nephrol 6:74-77

48. Al-Eisa AA, Samhan M, Naseef M (2004) End-stage renal disease in Kuwaiti children: an 8-year experience. Transplant Proc 36:1788-1791

49. White A, Wong W, Sureshkumur P, Singh G (2010) The burden of kidney disease in Indigenous children of Australia and New Zealand, epidemiology, antecedent factors and progression to chronic kidney disease. J Paediatr Child Health 46:504-509

50. Van der Heijden BJ, van Dijk PC, Verrier-Jones K, Jager KJ, Briggs JD (2004) Renal replacement therapy in children: data from 12 registries in Europe. Pediatr Nephrol 19:213-221

51. Registry of the Nephrology, Dialysis and Transplantation in Turkey (2009) Turkish Society of Nephrology Registry 2008, Istanbul. http://www.tsn.org.tr

52. McDonald SP, Craig JC, Australian and New Zealand Paediatric Nephrology Association (2004) Long-term survival of children with end-stage renal disease. N Engl J Med 350:2654-2662

53. Groothoff JW, Gruppen MP, Offringa M, Hutten J, Lilien MR, Van De Kar NJ, Wolff ED, Davin JC, Heymans HS (2002) Mortality and causes of death of end-stage renal disease in children: a Dutch cohort study. Kidney Int 61:621-629

54. Gillen DL, Stehman-Breen CO, Smith JM, McDonald RA, Warady BA, Brandt JR, Wong CS (2008) Survival advantage of pediatric recipients of a first kidney transplant among children awaiting kidney transplantation. Am J Transplant 8:2600-2606

55. Mekahli D, Shaw V, Ledermann SE, Rees L (2010) Long-term outcome of infants with severe chronic kidney disease. Clin J Am Soc Nephrol 5:10-17

56. Kramer A, Stel VS, Tizard J, Verrina E, Rönnholm K, Pálsson R, Maxwell H, Jager KJ (2009) Characteristics and survival of young adults who started renal replacement therapy during childhood. Nephrol Dial Transplant 24:926-933

57. Dharnidharka VR, Stablein DM, Harmon WE (2004) Posttransplant infections now exceed acute rejection as cause for hospitalization: a report of the NAPRTCS. Am J Transplant 4:384-389

58. Staples AO, Greenbaum LA, Smith JM, Gipson DS, Filler G, Warady BA, Martz K, Wong CS (2010) Association between clinical risk factors and progression of chronic kidney disease in children. Clin J Am Soc Nephrol 5:2172-2179

59. González Celedón C, Bitsori M, Tullus K (2007) Progression of chronic renal failure in children with dysplastic kidneys. Pediatr Nephrol 22:1014-1020

60. Keijzer-Veen MG, Schrevel M, Finken MJ, Dekker FW, Nauta J, Hille ET, Frölich M, van der Heijden BJ; Dutch POPS-19 Collaborative Study Group (2005) Microalbuminuria and lower glomerular filtration rate at young adult age in subjects born very 
premature and after intrauterine growth retardation. J Am Soc Nephrol 16:2762-2768

61. Köttgen A (2010) Genome-wide association studies in nephrology research. Am J Kidney Dis 56:743-758

62. Jafar TH, Stark PC, Schmid CH, Landa M, Maschio G, de Jong PE, de Zeeuw D, Shahinfar S, Toto R, Levey AS; AIPRD Study Group (2003) Progression of chronic kidney disease: the role of blood pressure control, proteinuria, and angiotensin-converting enzyme inhibition: a patient-level meta-analysis. Ann Intern Med 139:244-252

63. Wingen AM, Fabian-Bach C, Schaefer F, Mehls O (1997) Randomised multicentre study of a low-protein diet on the progression of chronic renal failure in children. European Study Group of Nutritional Treatment of Chronic Renal Failure in Childhood. Lancet 349:1117-1123

64. Ardissino G, Testa S, Daccò V, Viganò S, Taioli E, Claris-Appiani A, Procaccio M, Avolio L, Ciofani A, Dello Strologo L, Montini G; Ital Kid Project (2004) Proteinuria as a predictor of disease progression in children with hypodysplastic nephropathy. Data from the Ital Kid Project. Pediatr Nephrol 19:172-177

65. Flynn JT, Mitsnefes M, Pierce C, Cole SR, Parekh RS, Furth SL, Warady BA; Chronic Kidney Disease in Children Study Group (2008) Blood pressure in children with chronic kidney disease: a report from the Chronic Kidney Disease in Children study. Hypertension 52:631-637

66. Mitsnefes M, Flynn J, Cohn S, Samuels J, Blydt-Hansen T, Saland J, Kimball T, Furth S, Warady B; CKiD Study Group (2010) Masked hypertension associates with left ventricular hypertrophy in children with CKD. J Am Soc Nephrol 21:137144

67. ESCAPE Trial Group, Wühl E, Trivelli A, Picca S, Litwin M, Peco-Antic A, Zurowska A, Testa S, Jankauskiene A, Emre S, Caldas-Afonso A, Anarat A, Niaudet P, Mir S, Bakkaloglu A, Enke B, Montini G, Wingen AM, Sallay P, Jeck N, Berg U, Caliskan S, Wygoda S, Hohbach-Hohenfellner K, Dusek J, Urasinski T, Arbeiter K, Neuhaus T, Gellermann J, Drozdz D, Fischbach M, Möller K, Wigger M, Peruzzi L, Mehls O, Schaefer F (2009) Strict blood-pressure control and progression of renal failure in children. N Engl J Med 361:1639-1650

68. Wang Y, Chen X, Song Y, Caballero B, Cheskin LJ (2008) Association between obesity and kidney disease: a systematic review and meta-analysis. Kidney Int 73:19-33

69. Abitbol CL, Chandar J, Rodríguez MM, Berho M, Seeherunvong W, Freundlich M, Zilleruelo G (2009) Obesity and preterm birth: additive risks in the progression of kidney disease in children. Pediatr Nephrol 24:1363-1370

70. De Brito-Ashurst I, Varagunam M, Raftery MJ, Yaqoob MM (2009) Bicarbonate supplementation slows progression of CKD and improves nutritional status. J Am Soc Nephrol 20:20752084

71. Rossert J, Levin A, Roger SD, Hörl WH, Fouqueray B, Gassmann-Mayer C, Frei D, McClellan WM (2006) Effect of early correction of anemia on the progression of CKD. Am J Kidney Dis 47:738-750

72. Ravani P, Malberti F, Tripepi G, Pecchini P, Cutrupi S, Pizzini P, Mallamaci F, Zoccali C (2009) Vitamin D levels and patient outcome in chronic kidney disease. Kidney Int 75:88-95

73. Fliser D, Kollerits B, Neyer U, Ankerst DP, Lhotta K, Lingenhel A, Ritz E, Kronenberg F; MMKD Study Group, Kuen E, König P, Kraatz G, Mann JF, Müller GA, Köhler H, Riegler P (2007) Fibroblast growth factor 23 (FGF23) predicts progression of chronic kidney disease: the Mild to Moderate Kidney Disease (MMKD) Study. J Am Soc Nephrol 18:2600-2608

74. Feig DI (2009) Uric acid: a novel mediator and marker of risk in chronic kidney disease? Curr Opin Nephrol Hypertens 18:526-530

75. Muntner P, Coresh J, Smith JC, Eckfeldt J, Klag MJ (2000) Plasma lipids and risk of developing renal dysfunction: the atherosclerosis risk in communities study. Kidney Int 58:293-301

76. Furth SL, Cole SR, Fadrowski JJ, Gerson A, Pierce CB, Chandra M, Weiss R, Kaskel F, Council of Pediatric Nephrology and Urology, New York/New Jersey; Kidney and Urology Foundation of America (2007) The association of anemia and hypoalbuminemia with accelerated decline in GFR among adolescents with chronic kidney disease. Pediatr Nephrol 22:265-271

77. Querfeld U, Anarat A, Bayazit AK, Bakkaloglu AS, Bilginer Y, Caliskan S, Civilibal M, Doyon A, Duzova A, Kracht D, Litwin M, Melk A, Mir S, Sözeri B, Shroff R, Zeller R, Wühl E, Schaefer F; 4 C Study Group (2010) The Cardiovascular Comorbidity in Children with Chronic Kidney Disease (4 C) study: objectives, design, and methodology. Clin J Am Soc Nephrol 5:1642-1648

78. Furth SL, Cole SR, Moxey-Mims M, Kaskel F, Mak R, Schwartz G, Wong C, Muñoz A, Warady BA (2006) Design and methods of the Chronic Kidney Disease in Children (CKiD) prospective cohort study. Clin J Am Soc Nephrol 1:1006-1015

Answers
1. a
2. c
3. $\mathrm{e}$
4. c
5. b

